\title{
Regulation of Immunoglobulin E Antibody Synthesis in Man by Antiidiotypic Antibodies
}

\author{
Raif S. Geha and Marc Comunale, Division of Allergy, Children's Hospital \\ Medical Center, Department of Pediatrics, Harvard Medical School, \\ Boston, Massachusetts 02115
}

\begin{abstract}
A B S TRACT The effect of rabbit antiidiotypic antibody raised against human IgG $\mathrm{F}\left(\mathrm{ab}^{\prime}\right)_{2}$ anti-tetanus toxoid (TT) antibodies on the in vitro synthesis of TTspecific IgE antibody by peripheral blood lymphocytes (PBL) was examined in three subjects. Two of these subjects were allergic twins whose sera persistently contained IgE anti-TT antibodies. The third subject was a nonallergic individual who had a slightly elevated serum $\operatorname{IgE}(250 \mathrm{IU} / \mathrm{ml})$ and who exhibited a transient serum IgE anti-TT response after booster immunization with TT. After appropriate absorptions rabbit anti-idiotype (Id) IgG reacted with anti-TT antibodies of both IgG and IgE isotypes in an idiotypeand antigen-specific fashion. PBL and $B$ cells from the three subjects studied spontaneously synthesized TTspecific IgE in culture. In all three cases, adsorption of B cells over plastic plates coated with anti-Id before culture specifically decreased the synthesis of $\operatorname{IgE}$ antibodies to TT but did not affect the synthesis of $\operatorname{IgE}$ antibodies to ragweed antigen $E$ by PBL from the twin allergic subjects. Addition of anti-Id to cultures of PBL from all three subjects specifically inhibited the synthesis of TT-specific IgE. This inhibition was shown to be exerted both at the level of the B cells and via the generation of antigen-specific suppressor $T$ cells from radiosensitive precursors.
\end{abstract}

The present results indicate that the synthesis of antigen-specific $\operatorname{IgE}$ in man is subject to regulation by idiotypic anti-idiotypic interactions that can involve both $\mathrm{B}$ and $\mathrm{T}$ lymphocytes.

\section{INTRODUCTION}

Anti-Id antibodies have been shown to regulate immunoglobulin G (IgG) synthesis in experimental animals and in man (1-5). Recently, it has been shown in experimental animals that antibody of the IgE isotype shares idiotypic determinants with antibody of

Received for publication 13 January 1982 and in revised form 15 September 1982. the IgG isotype (6). Furthermore, Blaser et al. (7) have also shown that the in vivo IgE antibody response in mice is subject to regulation by idiotypic antiidiotypic interactions.

The role of anti-idiotype (Id) ${ }^{1}$ antibodies in the regulation of the human IgE response is unknown. Recently, it was demonstrated in our laboratory that human IgG and IgE antibodies to tetanus toxoid (TT) share idiotypic determinants (8) and that autoanti-Id antibodies arise during the course of the normal human immune response to TT antigen (9). These findings strongly raised the possibility that idiotypic antiidiotypic interactions may regulate the synthesis of human IgE. In the present communication we demonstrate that rabbit antibodies raised against Id determinants of human anti-TT antibodies can regulate the in vitro synthesis of anti-TT antibodies of the IgE isotype.

\section{METHODS}

Subjects. Three subjects were studied. Two of the subjects were 21-yr-old male identical twins. They had allergic rhinitis caused by multiple allergens, positive immediate hypersensitivity skin tests to multiple allergens, including ragweed, and elevated serum IgE levels $(850$ and $890 \mathrm{IU} / \mathrm{ml}$, respectively). Their sera studied serially over 1 yr before the present study were found persistently to contain IgE antibodies to TT as determined by the radioallergosorbent test (mean binding of ${ }^{125} \mathrm{I}$ anti-IgE to TT-coupled disks in the radio-allergo-sorbent test (RAST) assay, 9.3 and $8.5 \%$, respectively). Both subjects were studied in the fall; October through mid-November of 1980 . The third subject studied was a 29-yr-old female subject who showed no positive immediate hypersensitivity skin tests to a battery of 36 common allergens and whose serum contained $250 \mathrm{IU} / \mathrm{ml}$ of IgE. 1.5 yr before the present study this subject was given a booster immunization with TT. At that time it was noticed that IgE

${ }^{1}$ Abbreviations used in this paper: AgE, ragweed antigen E; Anti-Id, antiidiotypic; FCS, fetal calf serum; HBSS, Hanks' Balanced Salt Solution; HSA, human serum albumin; Id, idiotype; RAST, radio-allergo-sorbent test; TT, tetanus toxoid. 
anti-TT antibodies became detectable in her serum starting the 6 th $\mathrm{d}$ postimmunization until the end of the 2nd mo postimmunization (maximal percent binding in the RAST assay, $5.8 \%$ ).

Immediately before the present study all three subjects were boosted with TT ( $5 \mathrm{Lf}$ units). IgE antibodies reappeared in the serum of the third subject for a period extending from the 5 th d postimmunization to the end of the $3 \mathrm{rd}$ mo postimmunization (maximum percent binding in the RAST assay $6.4 \%$ ).

The purposes of the study were explained to the subjects and their written consent was obtained.

Antigens and antisera. TT and DT antigens were obtained from Massachusetts Biological Laboratories purified over Sephadex G-200 columns and radiolabeled with ${ }^{125}$ I as described in reference 10. Ragweed antigen $\mathrm{E}$ was obtained from Calbiochem Laboratories, La Jolla, CA and extensively dialyzed against phosphate-buffered saline (PBS). Human serum albumin (HSA) was obtained from the American Red Cross. Rabbit anti-human IgE raised in rabbits against IgE myeloma P.S. (a kind gift of Dr. Ishizaka) was absorbed extensively with pooled human IgG, IgM, and IgA myelomas and human kappa lambda Bence Jones proteins. Rabbit antihuman IgE used to coat the plastic plates in the solid-phase radioimmunoassay was immunosorbent purified over Sepharose $4 \mathrm{~B}$ cross-linked to P.S. myeloma IgE. By radioimmunoassays this immunosorbent purified rabbit anti-human IgE bound ${ }^{125} \mathrm{I}$ IgE (P.S.) and ${ }^{125} \mathrm{I}$ IgE (N.D.) myeloma proteins, but not human IgG, IgM, and IgA myelomas. The ${ }^{125} \mathrm{I}$ rabbit antihuman IgE used in the radioimmunoassay was purchased from Pharmacia Fine Chemicals, Piscataway, $\mathrm{NJ}$, as the RAST reagent and had a specific activity of $12 \mu \mathrm{Ci} / \mu \mathrm{g}$.

Determination of IgE and of antigen-specific IgE antibodies in the serum. Total IgE and antigen-specific IgE were determined in the serum using the commercially available PRIST and RAST assays (Pharmacia Fine Chemicals). TT and AgE were cross-linked to cyanogen bromide-activated cellulose disks as described in reference 11 . The specificity of the RAST was ascertained by showing that purified IgE but not IgG (10 $\mu$ g each) completely blocked the binding of ${ }^{125} \mathrm{I}$-anti-IgE to the antigen-coated disks preincubated with a known positive serum.

Production, absorption, and characterization of antiidiotypic antisera. Idiotypic antisera were raised in rabbits against $\operatorname{IgG}\left(\mathrm{Fab}^{\prime}\right)_{2}$ anti-TT antibodies isolated from the serum of each of the three subjects studied. The IgG $\left(\mathrm{Fab}^{\prime}\right)_{2}$ anti-TT was obtained 7 and $10 \mathrm{~d}$ after a booster immunization with TT that was given 1 yr or more before the present study. The antisera were prepared as described in reference 10 except that the IgG-enriched fraction of human serum was absorbed extensively against the insolubilized IgG fraction of rabbit anti-human IgE (8). IgG $F\left(a^{\prime}\right)_{2}$ fragments obtained by pepsin digestion followed by Sephadex G-150 chromatography were passed over a TT-immunosorbent column pretreated with NaSCN. The material that did not bind to the column was designated as TT nonreactive IgG $\mathrm{F}\left(\mathrm{ab}^{\prime}\right)_{2}$. The material that was bound to the TT column (4-7 mg) was eluted with $3 \mathrm{M} \mathrm{NaSCN}$ and designated IgG $\mathrm{F}\left(\mathrm{ab}^{\prime}\right)_{2}$ antiTT or "idiotype". This material contained $<50 \mathrm{pg} / \mathrm{ml}$ of IgE as determined by a solid-phase radioimmunoassay described below. It was used to immunize a rabbit as described in reference 10. IgG was isolated from the rabbit serum by DEAE column chromatography and suspended at $10 \mathrm{mg} / \mathrm{ml}$ in PBS. $10 \mathrm{ml}$ of rabbit anti-Id IgG was absorbed twice, respectively, with $(a) 2 \mathrm{~g}$ of Sepharose-bound TT nonreactive $\operatorname{IgG~} \mathrm{F}\left(\mathrm{ab}^{\prime}\right)_{2}$ derived from the idiotype donor. (b) $2 \mathrm{~g}$ of Se- pharose-bound pooled human IgG (Cohn fraction II), (c) l $\mathrm{ml}$ of packed erythrocytes obtained from the idiotype donor, (d) $1 \mathrm{ml}$ of packed nylon wool purified $\mathrm{T}$ cells derived from leukopheresis units, and $(e) 1 \mathrm{ml}$ of packed Epstein-Barr virus (EBV) transformed human $B$ cell line.

The capacity of rabbit anti-Id IgG to bind ${ }^{125}$ I-idiotype and to inhibit the binding of ${ }^{125}$ I-labeled TT to IgG and to IgE from the idiotype donor were assessed as described in reference $10.10 \mu \mathrm{g}$ of $\mathrm{F}\left(\mathrm{ab}^{\prime}\right)_{2}$ anti-TT were radiolabeled with ${ }^{125}$ I to a specific activity of $2-4,000 \mathrm{cpm} / \mathrm{ng}$. Each of a set of conical plastic Beckman microfuge tubes (Beckman Instruments, Inc., Wakefield, MA) received 10-20 ng of ${ }^{125}$ I $\mathrm{F}\left(\mathrm{ab}^{\prime}\right)_{2}$ anti-TT followed by $100 \mu \mathrm{l}$ of different dilutions of preimmune or immune rabbit IgG in PBS. After an incubation period of $1 \mathrm{~h}$ at $37^{\circ} \mathrm{C}$, normal rabbit serum and goat anti-rabbit IgG were added at equivalence (taking into consideration the contribution of preimmune or immune rabbit IgG). The tubes were incubated again at $37^{\circ} \mathrm{C}$ for $1 \mathrm{~h}$, then at $4^{\circ} \mathrm{C}$ overnight. The precipitates that formed were washed in a Beckman microcentrifuge for $5 \mathrm{~min}$ at $12,000 \mathrm{rpm}$ with ice-cold PBS containing $0.5 \%$ human serum albumin and $0.5 \%$ Tween 20 (washing buffer). After three washes the precipitates were counted for radioactivity in a Tri-Carb gamma scintillation counter (Packard Instrument Co., Inc., Downers Grove, IL). To determine whether anti-Id recognized antigen binding sites on IgG, the dilution of human IgG necessary to precipitate $70 \%$ of the total amount of precipitable radiolabeled TT was determined. Each of a set of Beckman microfuge tubes received in succession $10 \mathrm{ng}$ of radiolabeled antigen, different dilutions of preimmune or postimmune rabbit IgG (preabsorbed with Sepharose 4-B cross-linked to TT and DT), and $100 \mu$ lof the appropriate dilution of human IgG determined above. After an incubation period of $1 \mathrm{~h}$ at $37^{\circ} \mathrm{C}$, myeloma IgG and rabbit antihuman IgG were added at equivalence and the precipitates were processed as described above. To determine whether anti-Id inhibited antigen binding to IgE, cellulose disks crosslinked to rabbit anti-human IgE were obtained from Pharmacia Diagnostics and the disks were incubated for $6 \mathrm{~h}$ at room temperature with $0.1 \mathrm{ml}$ of a dilution of human serum, which resulted in the binding of $70 \%$ of the radioactivity in $10 \mathrm{ng}$ of ${ }^{125} \mathrm{I}-\mathrm{TT}$ or ${ }^{125} \mathrm{I}-\mathrm{AgE}$. The disks were then washed extensively with washing buffer, incubated overnight at room temperature with $10 \mathrm{ng}$ of ${ }^{125} \mathrm{I}$-radiolabeled antigen in the presence or absence of antiidiotypic antiserum. After extensive washing the disks were counted for radioactivity.

Cell isolation and fractionation. Heparinized blood was obtained from the subjects between the 8th and 35th d postimmunization. Mononuclear cells were isolated from peripheral blood over Ficoll-hypaque and washed five times with Hanks' Balanced Salt Solution (HBSS) prior to further fractionation.

$\mathrm{T}$ cells were obtained by rosetting mononuclear cells with neuraminidase-treated sheep erythrocytes $(E)$ and recovering the $E$ rosette-forming cells from the bottom of a Ficollhypaque gradient after lysis of erythrocytes with Tris-buffered $0.87 \% \mathrm{NH}_{4} \mathrm{Cl}$. Cells that did not form rosettes with $\mathrm{E}$ were recovered from the top of the Ficoll gradient, and used as a $B$ cell-rich suspension. The details of these procedures and the composition of the cell fractions are found in reference 12

Cell cultures for the measurement of IgE synthesis in vitro. Cells were suspended at a concentration of $1 \times 10^{6} /$ $\mathrm{ml}$ in RPMI 1640 medium containing $10 \%$ fetal calf serum (FCS), penicillin $(100 \mu / \mathrm{ml})$ and streptomycin $(50 \mu \mathrm{g} / \mathrm{ml})$ and cultured in triplicate in $1-\mathrm{ml}$ aliquots in $12 \times 75-\mathrm{mm}$ sterile plastic tubes. After $7 \mathrm{~d}$ of incubation in $5 \% \mathrm{CO}_{2}$ in 
air at $37^{\circ} \mathrm{C}$ the culture fluid supernatants were collected and assayed for their content of total IgE and of antigen-specific $\mathrm{IgE}$. At the initiation of the cultures $1-\mathrm{ml}$ aliquots of cell suspension were frozen and thawed three times, allowed to incubate for $7 \mathrm{~d}$ at $37^{\circ} \mathrm{C}$, then spun at $200 \mathrm{~g}$ for $10 \mathrm{~min}$ and their supernatants were collected. Parallel 6-d cultures were carried in the presence of cycloheximide (Sigma Chemical Co., St. Louis, MO, $100 \mu \mathrm{g} / \mathrm{ml}$ ) to ascertain that the IgE measured at the end of the 6-d culture period represented de novo synthesized IgE.

Radioimmunoassay of IgE in culture supernatants. IgE present in culture supernatants were determined by a solidphase radioimmunoassay as described (13). Triplicate wells of a plastic polyvinyl 96-well microtiter plate (Dynatech Laboratories, Inc., Alexandria, VA) were coated with a 0.4$\mathrm{mg} / \mathrm{ml}$ solution of immunosorbent purified rabbit anti human IgE (P.S.) by placing $200 \mu \mathrm{l}$ of the reagent in the Vshaped wells. This reagent was derived from the IgG fraction of the serum of a rabbit immunized with purified myeloma P.S. (a kind gift of Dr. Ishizaka). This rabbit IgG was absorbed with insolubilized human myelomas IgG, IgM, IgA, and with $K$ and $L$ Bence Jones proteins, then immunosorbent-purified over an IgE P.S. column. It reacted solely with ${ }^{125} \mathrm{I}-\mathrm{IgE}$ (P.S. and N.D. the latter a gift of Dr. Johansson, Uppsala, Sweden), but not with ${ }^{125}$ I radiolabeled IgG, IgA, $\operatorname{IgM}, \mathrm{K}$, or $\mathrm{L}$ chains. The rabbit anti-IgE-containing plates were incubated for $16 \mathrm{~h}$ in a humidified chamber at room temperature. The wells were aspirated, washed twice with PBS, filled for $2 \mathrm{~h}$ at room temperature with a $10 \%$ solution of HSA then washed thrice with PBS-1\% bovine serum albumin (BSA). Duplicate wells then received $200 \mu \mathrm{l}$ of sample or standard and after an overnight incubation at room temperature were aspirated, washed three times in PBS-1\%, HSA-0.05\%, Tween 20, twice in PBS (washing buffer), and then received $200 \mu \mathrm{l}$ of ${ }^{125} \mathrm{I}$ rabbit anti-human IgE obtained from Pharmacia, Inc. (RAST reagent, sp act, $12 \mu \mathrm{Ci} / \mu \mathrm{g}$ ). After a 6-h incubation the wells were aspirated, washed three times with washing buffer, three times with PBS, and five times with distilled water. The wells were then cut and their content of radioactivity was measured in a gamma spectrometer (model 1185, Tracor Analytic, Stamford, CT) by counting over a 10 -min interval.

IgE values were read from a standard curve constructed using known amounts of IgE. Nonspecific binding of IgE to plates coated with HSA was negligible $(\sim 40 \mathrm{cpm})$. Also there was negligible binding $(<50 \mathrm{cpm})$ to anti-IgE coated wells that received $0.1 \mathrm{ml}$ of $100 \mu \mathrm{g} / \mathrm{ml}$ solutions of IgG, IgM, and IgA myeloma proteins. We used the commercial Pharmacia reference standards for calibrations. Essentially identical standard curves were obtained. The lower limit of the sensitivity of this assay varied between 50 and $150 \mathrm{pg} / \mathrm{ml} \mathrm{de}$ pending on the interval of time elapsed between the iodination of the rabbit ${ }^{125} \mathrm{I}$-anti-human IgE and the performance of the assay. The amount of de novo $\mathrm{IgE}$ present in the supernatant of a given culture was determined to be the total amount of IgE present in that supernatant minus the mean IgE present in the supernatants of the triplicate parallel cultures to which cycloheximide has been added.

Radioimmunoassay of antigen-specific IgE in culture supernatants. This assay was performed exactly as the assay for total IgE except that the plates were coated with $1 \mathrm{mg} /$ $\mathrm{ml}$ solution of TT antigen or ragweed antigen $\mathrm{E}$.

The net counts per minute of ${ }^{125} \mathrm{I}$ anti-IgE bound to antigen-coated wells preincubated with culture supernatants was obtained by subtracting the counts per minute of ${ }^{125} I$ anti-IgE bound in the presence of supernatants of cycloheximide-treated cultures (mean of triplicates usually $<100$ cpm) from the counts per minute of ${ }^{125} I$ anti-IgE bound in the presence of supernatants from the untreated cultures. The specificity of this assay was established by demonstrating that addition of TT antigen $(1 \mu \mathrm{g} /$ well $)$ to the samples tested blocked completely the binding of ${ }^{125}$ I anti-IgE to the wells. The content of antigen-specific IgE in a given supernatant was compared with the content of antigen-specific IgE in a standard serum pool obtained by pooling of the sera of subjects 1 and 2 at a $1: 1$ ratio. Dilutions of this serum pool were made in RPMI 1640 medium containing $10 \%$ FCS. Nonspecific binding of ${ }^{125}$ I anti-IgE to plates coated with antigen (TT and AgE) and preincubated with culture medium was always $<45 \mathrm{cpm}$ and was subtracted from the counts per minute of ${ }^{125} \mathrm{I}$ anti-IgE bound in the presence of the dilutions of the standard serum pool. $1 \mathrm{ml}$ of a $1 / 100$ dilution of the standard pool was arbitrarily assigned a content of 2,000 U of TT-specific IgE antibody and 2,000 U of AgE-specific IgE antibody. Fig. 1 depicts the relationship between counts per minute of ${ }^{125} I$ anti-IgE bound to wells coated with AgE or TT and incubated with various dilutions of the standard pool. Samples in which the net binding of ${ }^{125} \mathrm{I}$ anti-IgE exceeded threefold the background ( $\left.\sim 45 \mathrm{cpm}\right)$ were considered to be positive. Thus, the lower limit of sensitivity of the assay was $\sim 11 \mathrm{U}(55 \mathrm{U} / \mathrm{ml})$ of TT-specific IgE and $\sim 7 \mathrm{U}(35 \mathrm{U} / \mathrm{ml})$ of AgE-specific IgE. The coefficient of variation of triplicate determinants averaged $14 \pm 8 \%$. The coefficient of variation between the means of four determinations performed at four different times on three different samples averaged 15,21 , and $13 \%$, respectively.

Absorption of $B$ cells on plates coated with rabbit antiId IgG. Plastic petri dishes were incubated overnight at room temperature with a $1-\mathrm{mg} / \mathrm{ml}$ solution of rabbit Id IgG

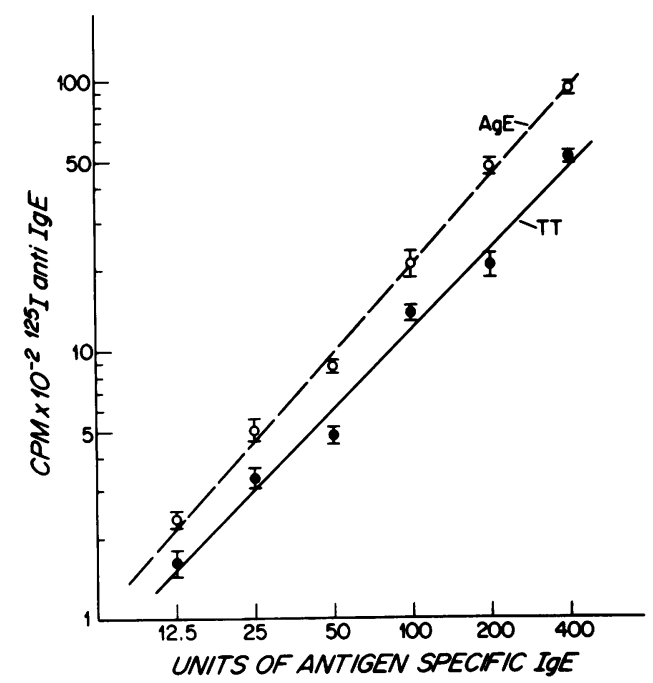

FigURE 1 Standard curve for radioimmunoassay of antigenspecific IgE. Numbers on the abscissa represent units of antigen-specific IgE with the content of $1 \mathrm{ml}$ of standard serum pool being assigned an arbitrary value of $2,000 \mathrm{U}$. Numbers on the ordinate represent net counts per minute of ${ }^{125} \mathrm{I}$ antiIgE bound to wells coated with TT or $\mathrm{AgE}$ and incubated with $200 \mu$ l of different dilutions of the standard pool. Net counts per minute were obtained by subtracting the counts per minute bound in the absence of the standard $(\simeq 45 \mathrm{cpm}$ ) from the total counts per minute. All determinations were done in triplicate. 
in PBS, then extensively washed in PBS. B cell-enriched cell suspensions $\left(4 \times 10^{6}\right.$ cells $\left./ \mathrm{ml}\right)$ depleted of monocytes by adherence overnight over plastic petri dishes were then allowed to incubate in the IgG-coated dishes for $1 \mathrm{~h}$ at room temperature, after which the nonadherent cells were gently aspirated, counted, and resuspended in culture medium.

Statistical analysis. Statistical analysis was performed by the two-tailed Student's $t$ test.

\section{RESULTS}

Characteristics of the anti-Id Antisera. The characteristics of the three anti-Id antisera used in the present study are shown in Fig. $2.1 \mathrm{mg}$ of rabbit anti-Id IgG precipitated a sizeable fraction (34-41\%) of the ${ }^{125}$ I-labeled IgG $\mathrm{F}\left(\mathrm{ab}^{\prime}\right)_{2}$ anti-TT, used for immunization (Fig. 2). In contrast, rabbit anti-Id IgG precipitated negligible amounts of ${ }^{125} \mathrm{I}$-labeled TT nonreactive IgG $\mathrm{F}\left(\mathrm{ab}^{\prime}\right)_{2}$ derived from the "idiotype" donor (Fig. 1) and negligible amounts $(<2 \%)$ of pooled ${ }^{125} \mathrm{I}$ IgG and negligible amounts $(<3 \%)$ of ${ }^{125} \mathrm{I} \operatorname{IgG~} \mathrm{F}\left(\mathrm{ab}^{\prime}\right)_{2}$ anti-TT obtained from three unrelated donors (data not shown).

Each of the three anti-Id IgG reacted with the antigen binding site of IgG from the corresponding idiotype donor as demonstrated by their capacity to inhibit the binding of ${ }^{125} \mathrm{I}$-TT, but not of ${ }^{125} \mathrm{I}$-diphtheria toxoid, to IgG obtained from that donor 1 wk after the recent booster immunization (Fig. 2). Rabbit anti-Id IgG did not inhibit ( $<3 \%$ inhibition) the binding of ${ }^{125} \mathrm{I}$-TT to IgG derived from unrelated donors (data not shown).

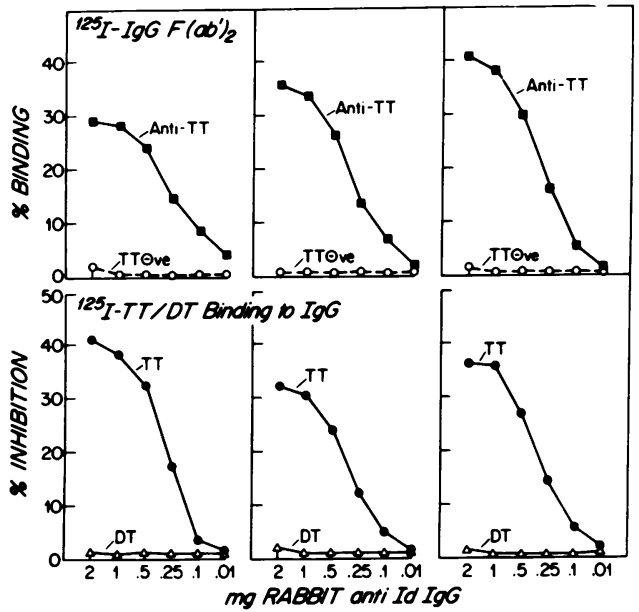

Figure 2 Characteristics of rabbit anti-Id IgG. The upper panels depict the binding of ${ }^{125} \mathrm{I}-\mathrm{IgG} \mathrm{F}\left(\mathrm{ab}^{\prime}\right)_{2}$ anti-TT "idiotype" ( $\sim 60,000 \mathrm{cpm}, \sim 10 \mathrm{ng})$ and of ${ }^{125} \mathrm{I}-\mathrm{TT}$ nonreactive $\operatorname{IgGF}\left(\mathrm{ab}^{\prime}\right)_{2}$ designated TT negative $(\sim 80,000 \mathrm{cpm}, \sim 10 \mathrm{ng})$ to anti-Id IgG. The lower panels depict the inhibition of ${ }^{125}$ ITT $(\sim 60,000 \mathrm{cpm}, \sim 10 \mathrm{ng})$ and ${ }^{125}$ I-DT $(\sim 35,000 \mathrm{cpm}$, $\sim 10 \mathrm{ng}$ ) binding to IgG under conditions of limiting amounts of IgG resulting in the binding of $\sim 70 \%$ of the radiolabeled antigen. All three subjects were immune to DT antigen.
The effect of rabbit anti-Id IgG on the binding of IgE to TT and ragweed antigen is shown in Fig. 3. The serum was obtained $1 \mathrm{wk}$ after the recent booster immunization. Rabbit anti-Id IgG inhibited in a dosedependent fashion the binding of TT but not of AgE to IgE derived from the idiotype donor. The binding of TT to IgE from an unrelated donor was not affected by rabbit anti-Id IgG (data not shown).

In vitro synthesis of total IgE and of antigen-specific IgE. At the time of the present study, peripheral blood lymphocytes (PBL) from all three subjects studied synthesized significant amounts of $\operatorname{IgE}$ in vitro compared to $\mathrm{PBL}$ derived from normal nonallergic subjects (Table I). 6 mo after the present study PBL from the two allergic subjects continued to synthesize significant amounts of $\mathrm{IgE}$ in vitro, whereas PBL from the third subject synthesized very small amounts of IgE (100-200 pg/ml).

In all three subjects part of the de novo made IgE had specificity for TT antigen, and in the two ragweed allergic donors (subjects 1 and 2) de novo made IgE had specificity for AgE (Table I). The specificity of the IgE anti-TT and of the IgE antiragweed antibodies present in the supernatants was confirmed by demonstrating that TT $(10 \mu \mathrm{g} / \mathrm{ml})$ completely blocked the detection of $\operatorname{IgE}$ antibodies to TT but not of IgE antibodies to AgE and vice versa (data not shown). The IgE antibodies detected in the culture supernatants were made de novo in culture because addition of cycloheximide to the cultures reduced the $\mathrm{IgE}$ in the supernatant to the level of IgE detected in supernatants of cultures of frozen and thawed cells (data not shown). The IgE antibodies detected in our assay could not have been due to nonspecific aggregation of IgE and antigen-specific IgG secreted in the supernatants

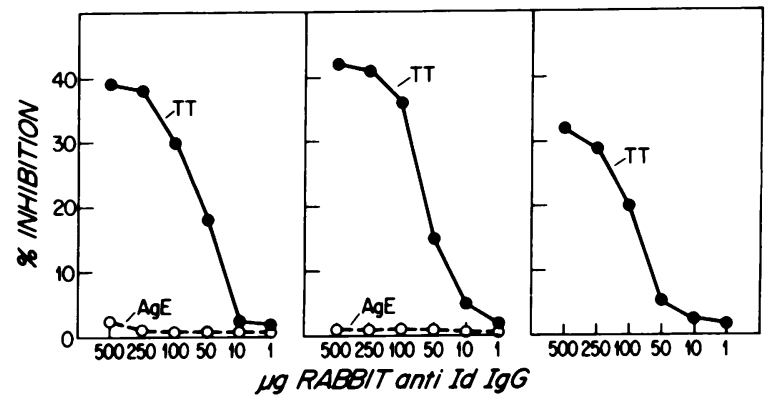

Figure 3 Inhibition of antigen binding to $\operatorname{IgE}$ by rabbit anti-Id IgG. In these experiments serum $\operatorname{IgE}$ was bound to anti-IgE-coated disk, the disks were washed and ${ }^{125} \mathrm{I}-\mathrm{TT}$ $(\sim 60,000 \mathrm{cpm}, \sim 10 \mathrm{ng})$ or ${ }^{125} \mathrm{I}-\mathrm{AgE}(\sim 45,000 \mathrm{cpm}, \sim 10$ ng) were added and the binding to the disks was assessed in the presence or absence of various amounts of rabbit antiId IgG (ref. 9). The experiments were carried under conditions of limiting amounts of IgE resulting in the binding of $\sim 70 \%$ of the radiolabeled antigen. 
TABLE I

In Vitro Synthesis of IgE by Unfractionated PBL

\begin{tabular}{lccc}
\hline & \multicolumn{3}{c}{ IgE Synthesis } \\
\cline { 2 - 4 } \multicolumn{1}{c}{ Source of PBL } & Total & Anti-TT & Anti-AgE \\
\hline & $p g / m l$ & $U / m l$ & $U / m l$ \\
Donor 1 & $2,120 \pm 128$ & $178 \pm 13$ & $385 \pm 37$ \\
Donor 2 & $2,680 \pm 173$ & $216 \pm 25$ & $369 \pm 22$ \\
Donor 3 & $382 \pm 28$ & $142 \pm 14$ & Not detectable \\
$\begin{array}{l}\text { Normal } \\
\quad \text { nonallergic } \\
\text { donors, } n=6\end{array}$ & & & \\
\hline
\end{tabular}

Values represent the mean $\pm \mathrm{SD}$ of triplicate cultures containing 2 $\times 10^{6}$ cells $/ \mathrm{ml}$. Similar results are obtained in two other separate experiments.

because prior absorption of supernatants with Staphylococcus aureus (Cowan I strain) did not affect the amount of antigen-specific IgE antibodies detected in the assay $(<10 \%$ reduction).

Binding of IgE $B$ cells to anti-Id coated plates. To determine if $B$ cells committed to antigen-specific IgE antibody synthesis bear idiotypic determinants we studied the effect of adsorbing B cells over anti-Idcoated plates on their ability to synthesize antibodies. We first established that enriched population of B cells from the three subjects studied synthesize IgE in the absence of additional autologous $\mathrm{T}$ cells (Table II). Addition of autologous $T$ cells (at a 1:1 ratio) resulted in a minimal increase in $\operatorname{IgE}$ synthesis averaging $21 \pm 9 \%$ for the three subjects. B cells absorbed for 1

TABLE II

Adsorption of B Cells over Anti-Ig-coated Plates

\begin{tabular}{llccc}
\hline & & \multicolumn{3}{c}{ IgE Synthesis, pg/ml } \\
\cline { 3 - 5 } $\begin{array}{c}\text { Source of } \\
\text { B cells }\end{array}$ & Immunosorbent & Total & Anti-TT & Anti-AgE \\
\hline & & $p g / m l$ & $U / m l$ & $U / m l$ \\
Donor 1 & Preimmune IgG & $3,711 \pm 265$ & $232 \pm 15$ & $473 \pm 22$ \\
& Anti-Id IgG & $3,625 \pm 360$ & $107 \pm 10$ & $519 \pm 23$ \\
& & & $(P<0.01)$ & \\
Donor 2 & Preimmune IgG & $4,303 \pm 458$ & $330 \pm 18$ & $447 \pm 34$ \\
& Anti-Id IgG & $4,190 \pm 173$ & $184 \pm 13$ & $421 \pm 21$ \\
& & & $(P<0.01)$ & \\
Donor 3 & Preimmune IgG & $586 \pm 24$ & $160 \pm 13$ & - \\
& Anti-Id IgG & $508 \pm 22$ & $87 \pm 9$ & - \\
& & & $(P<0.01)$ & \\
\hline
\end{tabular}

Values represent the mean \pm SD of triplicate cultures containing 2 $\times 10^{6}$ cells $/ \mathrm{ml}$. Similar results were obtained in two other separate experiments. $\mathrm{h}$ at room temperature over plastic dishes coated with anti-Id $(1 \mathrm{mg} / \mathrm{ml})$ synthesized significantly less $\mathrm{IgE}$ antibodies to TT than control B cells absorbed over plates coated with preimmune rabbit IgG (Table II). In contrast, the synthesis of IgE antibodies to $\mathrm{AgE}$ was not affected. The decrease in the synthesis of $\operatorname{IgE}$ antibody to TT was not due to interference by carried over anti-Id with the assay for IgE anti-TT. This is because supernatants of cycloheximide-treated cultures of anti-Id-absorbed B cells did not interfere with the assay for IgE anti-TT when they were added to supernatants of cultures of untreated B cells or to dilutions of serum derived from the idiotype donor (data not shown).

Effect of anti-Id on IgE synthesis by unfractionated PBL. The effect of anti-Id on IgE synthesis by unfractionated PBL derived from the idiotype donor is shown in Table III. In these experiments $500 \mu \mathrm{g} / \mathrm{ml}$ of anti-Id IgG were added during the first $48 \mathrm{~h}$ of culture then the cells were washed and recultured for $7 \mathrm{~d}$. This was done to remove anti-Id IgG from the cultures because it could interfere with the assay of TT-specific $\operatorname{IgE}$. The results obtained in these experiments are shown in Table III. They indicated that rabbit anti-Id IgG, but not preimmune rabbit IgG, inhibited the synthesis of TT-specific IgE antibodies. This inhibition was TT-specific because the synthesis of IgE antibodies to $\mathrm{AgE}$ was not affected (Table II). The inhibition of IgE anti-TT synthesis by anti-Id IgG was idiotype-specific because anti-Id IgG did not inhibit IgE anti-TT synthesis by PBL from subjects unrelated to the idiotype donor (data not shown).

TABLE III

Effect of Anti-Id IgG on IgE Synthesis

\begin{tabular}{llccc}
\hline & & \multicolumn{3}{c}{ IgE Synthesis } \\
\cline { 3 - 5 } $\begin{array}{c}\text { Source of } \\
\text { PBL }\end{array}$ & $\begin{array}{c}\text { Addition to the } \\
\text { culture }\end{array}$ & \multicolumn{1}{c}{ Total } & Anti-TT & Anti-AgE \\
\hline & & $p g / m l$ & $U / m l$ & $U / m l$ \\
Donor 1 & Preimmune IgG & $1,870 \pm 80$ & $232 \pm 17$ & $357 \pm 20$ \\
& Anti-Id IgG & $1,607 \pm 115$ & $163 \pm 8$ & $326 \pm 18$ \\
& & & $(P<0.02)$ \\
Donor 2 & Preimmune IgG & $2,446 \pm 85$ & $228 \pm 16$ & $273 \pm 21$ \\
& Anti-Id IgG & $2,377 \pm 101$ & $121 \pm 13$ & $284 \pm 14$ \\
& & & $(P<0.02)$ \\
Donor 3 & Preimmune IgG & $318 \pm 37$ & $120 \pm 10$ & - \\
& Anti-Id IgG & $258 \pm 25$ & $77 \pm 8$ & - \\
& & & $(P<0.05)$ \\
\hline
\end{tabular}

Values represent mean $\pm \mathrm{SD}$ of triplicate cultures. Rabbit IgG was added at a concentration of $1 \mathrm{mg} / \mathrm{ml}$ for the first $48 \mathrm{~h}$ of culture, then the cells were washed and recultured at a concentration of $2 \times 10^{6}$ viable cells $/ \mathrm{ml}$ for 5 additional $\mathrm{d}$. 
The inhibition of TT-specific IgE antibody synthesis by anti-Id IgG was not due to the interference of carried over anti-Id IgG with the assay for $\operatorname{IgE}$ anti-TT because supernatants of cells cultures treated for 48 $\mathrm{h}$ with anti-Id IgG, then washed and recultured for 7 $\mathrm{d}$ in the presence of cycloheximide, did not interfere with the assay of IgE anti-TT when mixed with supernatants of 7-d cultures of untreated autologous cells (Table IV) or with dilutions of serum derived from the idiotype donor (data not shown).

Effect of anti-Id on B and T cells. The anti-Idmediated inhibition of IgE anti-TT by unfractionated PBL could have resulted from idiotypic antiidiotypic interactions involving B cells, T cells, or both subpopulations of cells. To answer these questions the effects of pretreatment of $\mathrm{B}$ and $\mathrm{T}$ cell-enriched populations with anti-Id were examined.

Since B cell-rich populations synthesized $\operatorname{IgE}$ in the absence of additional $T$ cells, B cells were incubated with rabbit anti-Id IgG or preimmune rabbit anti-IgG $(500 \mu \mathrm{g} / \mathrm{ml})$ for $48 \mathrm{~h}$ at $37^{\circ} \mathrm{C}$, washed extensively, then cultured without addition of $\mathrm{T}$ cells. After $7 \mathrm{~d}$ the culture supernatants were assayed for IgE. The results of these experiments, as depicted in Table $\mathrm{V}$, indicate that anti-Id IgG specifically inhibited IgE anti-TT synthesis by $\mathrm{B}$ cells derived from the idiotype donor. This inhibition was antigen specific (Table V) and idiotype

TABLE IV

Effect of "Carried over" Anti-Id IgG on the Determination of IgE Anti-TT in PBL Culture Supernatants

\begin{tabular}{|c|c|c|}
\hline Material assayed & Addition ${ }^{*}$ & $\operatorname{lgE}$ anti TT \\
\hline & & $U / m l$ \\
\hline $\begin{array}{l}0.1 \mathrm{ml} \text { supernatant of } \\
7 \mathrm{~d} \text { PBL culture }\end{array}$ & $0.1 \mathrm{ml}$ of medium & $127 \pm 18$ \\
\hline $\begin{array}{l}0.1 \mathrm{ml} \text { supernatant } \\
7 \mathrm{~d} \text { PBL culture }\end{array}$ & $\begin{array}{l}0.1 \mathrm{ml} \text { of supernatant } \\
\text { from PBL cultures } \\
\text { treated for } 48 \mathrm{~h} \text { with } \\
\text { preimmune rabbit } \\
\text { lgG, washed, then } \\
\text { cultured for } 5 \mathrm{~d} \text { with } \\
\text { cycloheximide } \$\end{array}$ & $136 \pm 15$ \\
\hline $\begin{array}{l}0.1 \mathrm{ml} \text { supernatant } \\
7 \mathrm{~d} \text { PBL culture }\end{array}$ & $\begin{array}{l}0.1 \mathrm{ml} \text { of supernatant } \\
\text { from PBL cultures } \\
\text { treated for } 48 \mathrm{~h} \text { with } \\
\text { anti-Id IgG washed } \\
\text { then cultured for } 5 \mathrm{~d} \\
\text { with cycloheximide } \S\end{array}$ & $120 \pm 13$ \\
\hline
\end{tabular}

- None of the materials added contained any detectable IgE antiTT.

$\$$ Mean \pm SD of triplicate determinations.

\$ PBL were all derived from the same donor.
TABLE V

Effect of Pretreatment of B Cells with Anti-Id on IgE Synthesis

\begin{tabular}{llccc}
\hline & & \multicolumn{3}{c}{ IgE Synthesis } \\
\cline { 3 - 5 } $\begin{array}{c}\text { Source of } \\
\text { B cells }\end{array}$ & \multicolumn{1}{c}{ Pretreatment } & \multicolumn{1}{c}{ Total } & Anti-TT & Anti-AgE \\
\hline & & $p g / m l$ & $U / m l$ & $U / m l$ \\
Donor 1 & Preimmune IgG & $2,556 \pm 96$ & $177 \pm 24$ & $298 \pm 33$ \\
& Anti-Id IgG & $2,302 \pm 103$ & $102 \pm 15$ & $317 \pm 28$ \\
& & & $(P<0.07)$ & \\
Donor 2 & Preimmune IgG & $2,932 \pm 163$ & $202 \pm 20$ & $303 \pm 17$ \\
& Anti-Id IgG & $2,883 \pm 211$ & $135 \pm 9$ & $282 \pm 27$ \\
& & & $(P<0.05)$ & \\
Donor 3 & Preimmune IgG & $408 \pm 47$ & $122 \pm 11$ & - \\
& Anti-Id IgG & $350 \pm 48$ & $72 \pm 12$ & - \\
& & & $(P<0.05)$ & \\
\hline
\end{tabular}

Values represent mean $\pm \mathrm{SD}$ of triplicate cultures. B cell rich suspensions were incubated for $48 \mathrm{~h}$ with rabbit IgG, washed extensively then cultured at $2 \times 10^{6}$ viable cells $/ \mathrm{ml}$ for $5 \mathrm{~d}$.

specific in that it was not exerted on B cells from subjects unrelated to the idiotype donor (data not shown). Furthermore, as described in the preceding section the observed inhibition of $\operatorname{IgE}$ anti-TT synthesis was shown not to be due to the interference of carried over anti-Id in the assay for IgE anti-TT.

The possible effects of anti-Id on $T$ cells involved in the regulation of IgE antibody synthesis was examined by studying the effect of anti-Id treated $\mathrm{T}$ cells on IgE antibody synthesis. In these experiments purified populations of $T$ cells were incubated for $48 \mathrm{~h}$ with preimmune rabbit IgG $(500 \mu \mathrm{g} / \mathrm{ml})$ or rabbit antiId $\operatorname{IgG}(500 \mu \mathrm{g} / \mathrm{ml})$, extensively washed and then added at a 1:1 ratio to freshly obtained autologous B cells. As previously mentioned addition of autologous $T$ cells to $B$ cells resulted in a moderate enhancement of IgE synthesis (data not shown). The results depicted in Table VI demonstrate that $T$ cells preincubated with anti Id IgG selectively suppressed IgE anti-TT synthesis by B cells. Because anti-Id could inhibit IgE anti-TT synthesis by directly interacting with B cells (see Table V), it was imperative to demonstrate that the $T$ cell-mediated suppression was not due to carried over anti-Id. For this reason we examined the capacity of irradiated $(3,000 \mathrm{rad}) \mathrm{T}$ cells preincubated for 48 $\mathrm{h}$ with anti-Id to inhibit IgE anti-TT synthesis and we examined the capacity of $T$ cells preincubated for 1 $h$ with anti-Id to inhibit the synthesis of IgE anti-TT. As shown in Fig. 4, irradiated T cells treated with antiId failed to inhibit TT-specific IgG synthesis by B cells. Furthermore, in two instances tested (subjects 1 and 2) $\mathrm{T}$ cells incubated with anti-Id for $\mathrm{l} \mathrm{h}$, washed, then 
TABLE VI

Effect of Pretreatment of T Cells with Anti-Id IgG on IgE Synthesis

\begin{tabular}{llccc}
\hline & & \multicolumn{3}{c}{ IgE Synthesis } \\
\cline { 3 - 5 } $\begin{array}{c}\text { Source of } \\
\text { cells }\end{array}$ & $\begin{array}{c}\text { Pretreatment of } \\
\text { T cells }\end{array}$ & Total & Anti-TT & Anti-AgE \\
\hline & & $p g / m l$ & $U / m l$ & $U / m l$ \\
Donor 1 & Preimmune IgG & $2,420 \pm 163$ & $178 \pm 18$ & $425 \pm 13$ \\
& Anti-Id IgG & $2,401 \pm 84$ & $98 \pm 15$ & $423 \pm 32$ \\
& & & $(P<0.05)$ & \\
Donor 2 & Preimmune IgG & $2,620 \pm 198$ & $227 \pm 24$ & $395 \pm 48$ \\
& Anti-Id IgG & $2,528 \pm 130$ & $148 \pm 16$ & $338 \pm 44$ \\
& & & $(P<0.05)$ & \\
Donor 3 & Preimmune IgG & $407 \pm 27$ & $172 \pm 20$ & - \\
& Anti-Id IgG & $352 \pm 19$ & $103 \pm 16$ & - \\
& & & $(P<0.05)$ & \\
\hline
\end{tabular}

Values represent mean $\pm S D$ of triplicate cultures. These cultures contained equal numbers of fresh B cells and of autologous $\mathrm{T}$ cells that have been preincubated for $48 \mathrm{~h}$ with rabbit IgG then extensively washed.

added $48 \mathrm{~h}$ later to autologous $\mathrm{B}$ cells failed to inhibit IgE anti-TT synthesis ( 4 and $9 \%$ inhibition, respectively) whereas nonirradiated $\mathrm{T}$ cells incubated for 48 $\mathrm{h}$ with anti-Id inhibited IgE anti-TT synthesis (38 and
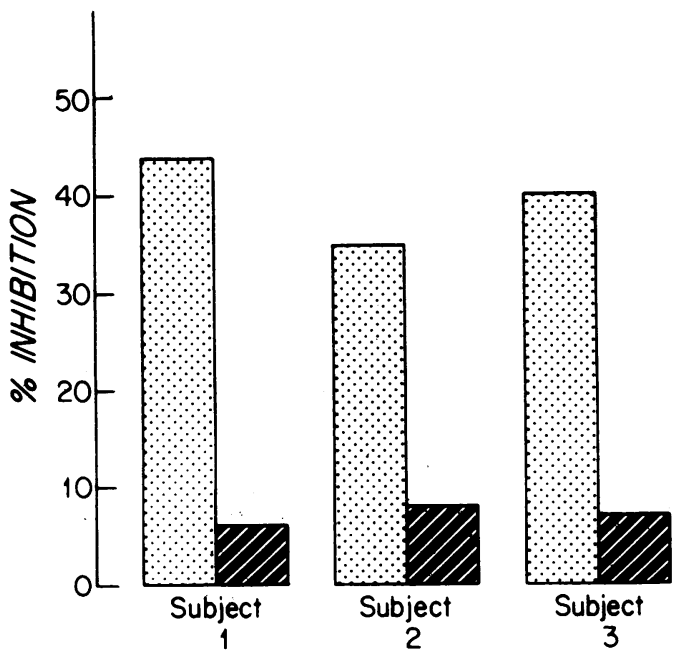

Figure 4 Effect of irradiation on the capacity of $T$ cells to suppress IgE anti-TT synthesis. Irradiated (3,000 rad) and nonirradiated $T$ cells were treated with anti-Id IgG or preimmune IgG $(500 \mu \mathrm{g} / \mathrm{ml})$ for $48 \mathrm{~h}$, washed then added at a $1: 1$ ratio to fresh B cells. $7 \mathrm{~d}$ later de novo made IgE was assayed in the culture supernatants. Percent inhibition for each subgroup of $\mathrm{T}$ cells (nonirradiated and irradiated) was calculated as: $100 \times 1-$ units of IgE in cultures with anti-Idtreated T cells/units of IgE in cultures with control-treated $\mathrm{T}$ cells. $\mathbb{Z}$, irradiated $\mathrm{T}$ cells; $\square$, T cells
$32 \%$, respectively). These results indicate that the precursors of antigen-specific IgE suppressor $\mathrm{T}$ cells induced by anti-Id are radiosensitive and that carried over anti-Id did not account for the inhibition of $\operatorname{IgE}$ anti-TT synthesis observed when anti-Id-treated nonirradiated $\mathrm{T}$ cells were added to B cell cultures.

\section{DISCUSSION}

The present study demonstrates that the in vitro synthesis of TT-specific IgE in man is accessible to regulation by anti-Id antibodies.

This study was made possible because a sensitive and specific radioimmunoassay enabled us to measure the in vitro synthesis of antigen-specific IgE (Fig. 1). Two of the three subjects included in our study were allergic individuals and their sera persistently contained IgE anti-TT antibodies. The third subject had a slightly elevated serum IgE level $(250 \mathrm{IU} / \mathrm{ml})$ with no clinical allergies. Her serum mounted a transient IgE response to TT after booster immunization. The transient development of serum IgE antibodies to injected antigens including TT in normal individuals has been previously reported $(14,15)$. PBL from each of the three individuals synthesized measurable quantities of IgE and IgE anti-TT when studied after booster immunization with TT (Table I). In addition, in vitro synthesis of IgE antibodies to ragweed antigen (AgE) by PBL was easily measured in the two ragweed allergic subjects. In contrast, PBL from nonallergic subjects synthesized negligible amounts of IgE and no detectable TT or AgE-specific IgE into their culture supernatants. These results are in agreement with the results of many previous investigators who uniformly have found that normal lymphocytes fail to secrete IgE spontaneously in vitro (16-21). The small amount of IgE synthesized by the third subject included in the present study could be explained by her slightly but definitely elevated serum $\operatorname{IgE}$, and by transient activation of her TT-specific IgE B cells. Transient activation of circulating antigen-specific IgE $B$ cells has been well documented by Saxon et al. (22).

The anti-Id antibodies used in the present study reacted after appropriate absorptions with only a fraction of the immunizing idiotype (Fig. 2) reflecting the fact that only some of the idiotypic determinants in the heteroclonal anti-TT response were present in sufficient quantities to induce an anti-Id response in the rabbit (10). Although the IgG $F\left(a b^{\prime}\right)_{2}$ anti-TT used for immunization contained no detectable $\operatorname{IgE}$, the rabbit anti-Id antisera showed idiotype- and antigen-specific reactivity with anti-TT antibodies of both IgG and IgE isotypes (Figs. 2 and 3 ) indicating that the two isotypes shared idiotypic determinants. In this regard rabbit anti-Id antibody raised against idiotype from subject 
1 was previously shown to elicit a Prausnitz-Kustner reaction in skin sites of normal recipients injected 48 $h$ previously with the IgE-enriched fraction of serum from the idiotype donor (8).

Absorption of B cells over anti-Id-coated plates specifically reduced their subsequent synthesis of $\operatorname{IgE}$ anti-TT (Table II) indicating that the surface immunoglobulin of B cells committed to the synthesis of $\operatorname{IgE}$ anti-TT shared Id determinants with serum antibody to TT. These findings also suggested that $\operatorname{IgE}$ B cells can serve as the targets for regulation by anti-Id antibody.

The signal delivered by Id anti-Id interactions to the IgE $B$ cells was an inhibitory signal because addition of anti-Id antibody to cultures of unfractionated PBL or of B cell-rich populations resulted in a specific inhibition of IgE anti-TT synthesis (Table III). This inhibition was not merely the result of antibody-dependent complement-mediated lysis of TT-specific B cells because $(a)$ there was no exogenous source of complement in the cultures, $(b)$ it was previously demonstrated that IgG anti-TT synthesis induced by nonspecific $T$ cell helper factor was not affected by anti-Id (5), thus making it unlikely that anti-Id-dependent complement lysis was operative in the in vitro cultures. Furthermore, the inhibition of IgE anti-TT synthesis by anti-Id could not have resulted from the potentially suppressive effects of histamine (23) liberated by the interaction of anti-Id and IgE anti-TT bound to the basophils that separate with mononuclear cells on Ficoll-hypaque. This is because the suppressive effects of histamine mediated by a radiosensitive $\mathrm{T}$ cell are nonspecific (24), yet the synthesis of IgE antibodies to $\mathrm{AgE}$ was not reduced in those cultures that received anti-Id.

The inhibition of TT-specific IgE synthesis by antiId operated via complex mechanisms. Two possible mechanisms were demonstrated in the present study. The first mechanism appeared to be $T$ cell-independent and occurred when anti-Id antibody was added to $B$ cell-rich cultures (Table V). Because the majority of IgE B cells have been shown to bear both surface $\operatorname{IgE}$ and $\operatorname{IgM}(25,26)$ it is not known whether idiotypic interactions involving either or both of these two surface idiotypes resulted in the inhibitory signal. Inhibition of immunoglobulin production of IgG and of IgM by anti-Id in man has been previously reported by us $(5,27)$ and by Bona and Fauci $(28)$. The mechanism of such inhibition is not well established. At least in one instance it appeared to be dependent on the presence of an intact $\mathrm{Fc}$ portion of the anti-Id antibody (27).

A second mechanism for the inhibition of TT-specific IgE synthesis by anti-Id was shown to be $\mathrm{T}$ cell dependent. Incubation of $\mathrm{T}$ cells with anti-Id resulted in the generation of antigen-specific suppressor $\mathrm{T}$ cells that caused inhibition of IgE anti-TT synthesis (Table VI). The precursor of this $T$ suppressor cell was shown to be radiosensitive and presumably was idiotype positive. Indeed, it is unlikely that the preparation of rabbit anti-Id IgG contained antibody that was directed against an idiotype-negative $\mathrm{T}$ cell-derived material that copurified from the serum with the $\operatorname{IgG~} \mathrm{F}\left(\mathrm{ab}^{\prime}\right)_{2}$ anti-TT used to raise the anti-Id antibody. In this regard, there is previous data in experimental animals and in man to indicate the presence of idiotype-positive $T$ cells that are activated by anti-Id antibody into idiotype-specific suppression (29-31).

The present work has important implications for the regulation of the IgE antibody response. First, it demonstrates that IgE antibody synthesis is subject to regulation by antiidiotypic antibody. Second, in view of our recent demonstration that auto-antiidiotypic antibodies arise during the course of the normal human immune response (9), the present study raises the possibility that IgE antibody synthesis in vivo, as well as in vitro, can be regulated by anti-Id. Third, it appears that anti-Id antibody can regulate in vitro IgE synthesis in nonallergic as well as in allergic subjects making it important to determine if there are in vivo differences between these two groups in so far as regulation of IgE synthesis by anti-Id antibody.

\section{ACKNOWLEDGMENTS}

The authors wish to thank Miss Melissa Smith for secretarial assistance and Dr. Fred Rosen for reviewing the manuscript.

This work was supported by US Public Health Service grant AI-05877 and by grants from the National Foundation, March of Dimes and the Rorer Corporation. Dr. Geha is a recipient of Allergic Diseases Academic Award 1 K07 AI 00440-01

\section{REFERENCES}

1. Eichmann, K., and K. Rajwesky. 1974. Induction of T and B cell immunity by anti-idiotypic antibody. Eur. J. Immunol. 5: 661-666.

2. Binz, H., and H. Wigzell. 1976. Shared idiotypic determinants on $B$ and $T$ lymphocytes reactive against the same antigenic determinants. V. Biochemical and serological characteristics of naturally occurring, soluble antigen-binding T-lymphocyte-derived molecules. Scand. J. Immunol. 5: 559-571.

3. Bona, C., and W. E. Paul. 1979. Cellular basis of regulation of expression of idiotype. I. T-suppressor cells specific for MOPC 460 idiotype regulate the expression of cells secreting anti-TNP antibodies bearing 460 idiotype. J. Exp. Med. 149: 591-600.

4. Weinberger, J. Z., R. N. Germain, B. Benacerraf, and M. E. Dorf. 1980. Hapten-specific T cell responses to 4hydroxy-3-nitrophenyl acetyl. V. Role of idiotypes in the suppressor pathway. J. Exp. Med. 152: 161-169.

5. Geha, R. S. 1979. Idiotypic determinants on human B cells. Clin. Res. 27: 47la. (Abstr.) 
6. Dessein, A., S. Ju, M. E. Dorf, B. Benacerraf, and R. N. Germain. 1980. IgG response to synthetic polypeptide antigens. II. Idiotypic analysis of the IgE response to LGlutamic Acid-L Alaine-L-Tyrosine (GAT). J. Immunol. 124: 71-76.

7. Blaser, K., T. Nakagawa, and A. L. DeWeck. 1980. Suppression of the benzyl penicilloyl-(BPO) specific IgE formation with isologous anti-idiotypic antibodies in BALB/c mice. J. Immunol. 125: 24-36.

8. Geha, R. S. 1981. Elicitation of Prausnitz-Kustner reaction by antiidiotypic antibody. J. Clin. Invest. 69(4): 735-741.

9. Geha, R. S. 1982. Detection of autoantiidiotypic antibody during the normal human immune response to tetanus toxoid antigen. J. Immunol. 129(1): 138-144.

10. Geha, R. S., and R. Weinberg. 1978. Antiidiotypic antisera in man. Production and immunochemical characterization of antiidiotypic antisera to human antitetanus toxoid antibodies. J. Immunol. 121: 1518-1523.

11. Ceska, M., R. Eriksson, and J. M. Varga. 1972. Radioimmunosorbent assay of allergen. J. Allergy Clin. Immunol. 49: 1-8.

12. Mudawwar, F., E. Yunis, and R. S. Geha. 1978. Antigenspecific helper factor in man. J. Exp. Med. 148: 10321043.

13. Geha, R. S., E. Reinherz, D. Leung, K. T. McKee, Jr., S. Schlossman, and F. S. Rosen. 1981. Deficiency of suppressor $\mathrm{T}$ cells in the hyperimmunoglobulin $\mathrm{E}$ syndrome. J. Clin. Invest. 68: 783-791.

14. Ishizaka, K. 1976. Cellular events in the IgE antibody response. Adv. Immunol. 23: 1-75.

15. Nagel, J., D. Srec, T. Waters, and P. Fireman. 1977. IgE synthesis in man. I. Development of specific IgE antibodies after immunization with tetanus-diphtheria $(\mathrm{Td})$ toxoids. J. Immunol. 118: 334-341.

16. Tjio, A. H., W. M. Hull, and G. J. Gleich. 1979. Production of human immunoglobulin $\mathrm{E}$ antibody in vitro. J. Immunol. 122: 2131-2133.

17. Sampson, H. A., and R. H. Buckley. 1981. Human IgE synthesis in vitro: A reassessment. J. Immunol. 127(3): 829-834.

18. Saxon, A., C. Morrow, and R. H. Stevens. 1980. Subpopulation of circulating $B$ cells and regulatory $T$ cells involved in in vitro immunoglobulin $\mathbf{E}$ production in atopic patients with elevated serum immunoglobulin $\mathrm{E}$. Clin. Invest. 63: 1457-1468.

19. Romagnani, S., G. F. Del Prete, E. Maggi, R. Troncone, G. M. Guidizi, F. Almerigogna, and M. Ricci. 1980. In vitro production of $\mathrm{IgE}$ by human peripheral blood mononuclear cells. II. Cells involved in the spontaneous
IgE production in atopic patients. Clin. Exp. Immunol. 42: 579-588.

20. Zuraw, B. L., M. Nonaka, C. O'Hair, and D. H. Katz. 1981. Human IgE antibody synthesis in vitro: Stimulation of IgE responses by pokeweed mitogen and selective inhibition of such responses by human suppressive factor of allergy (SFA). 127(3): 1169-1177.

21. Saryan, J. A., and R. S. Geha. Regulation of IgE synthesis in man. (Abstr.) American Society of Clinical Investigation. In press.

22. Mawhinney, H., and A. Saxon. 1981. Synthesis of specific IgE and IgG antibody in vitro during honey bee venom immunotherapy. J. Allergy Clin. Immunol 67(Suppl): 18.

23. Rocklin, R., J. Breard, S. Ciupta, R. Good, and K. Melmom. 1980. Characterization of the human lymphocytes that produce a histamine induced suppressor factor. Cell. Immunol. 51: 226-237.

24. Lima, M., and R. Rocklin. 1981. Histamine modulates in vitro IgE production by pokeweed mitogen stimulated human mononuclear cells. Cell. Immunol. 64: 324-336.

25. Ishizaka, K., T. Ishizaka, H. Okudaira, and H. Bazin. 1978. Ontogeny of $\operatorname{IgE}$ bearing lymphocytes in the rat. J. Immunol. 120: 655-660.

26. Saxon, A., M. Kaplan, and R. H. Stevens. 1980. Isotype specific human $B$ lymphocytes that produce immunoglobulin $\mathrm{E}$ in vitro when stimulated by pokeweed $\mathrm{mi}$ togen. J. Allergy Clin. Immunol. 66: 233-241.

27. Mudawwar, F., Z. Awdeh, K. Ault, and R. S. Geha. 1980. Regulation of $M$ component synthesis by antiidiotypic antibody in a patient with hypogammaglobulinemia. $J$. Clin. Invest. 65: 1202-1209.

28. Bona, C. A., and A. S. Fauci. 1980. In vitro idiotypic suppression of chronic lymphocytic leukemia lymphocytes secreting monoclonal immunoglobulin $\mathbf{M}$ antisheep erythrocyte antibody. J. Clin. Invest. 65: 761-767.

29. Weinberger, J. Z., R. N. Germain, S. I. Ju, M. I. Green, B. Benacerraf, and M. E. Dorf. 1979. Hapten-specific T-cell responses to 4-hydroxy-3-mitrophenyl acetyle. II Demonstration of idiotypic determinants on suppressor T cells. J. Exp. Med. 150: 761-776.

30. Bach, B. A., M. I. Green, B. Benacerraf, and A. Nisonoff. 1979. Mechanism of regulation of cell mediated immunity. IV. Azobenzene-arsonate specific suppressor factor(s) bear cross-reactive idiotypic determinants the expression which is linked to the heavy chain allotype linkage group of genes. J. Exp. Med. 149: 1084-1098.

31. Geha, R. S. 1980. Idiotypic determinants on human T cells. Clin. Res. 28(2): 503a. (Abstr.) 